Швець Ф. Д., к.т.н., доцент, Пахаренко О. В., к.е.н., доцент (Національний університет водного господарства та природокористування, м. Рівне)

\title{
ФОРМУВАННЯ РИНКУ ЗЕМЛІ В УКРАЇНІ: ЗАБАГАНКА ЧИ НЕОБХІДНІСТЬ
}

Наведено результати дослідження проблем становлення ринку землі в Україні. Проведено аналіз законопроектів про ринок земель в Україні та виявлено їх позитивні і негативні сторони. Запропоновано ряд практичних рекомендацій щодо розвитку ринку земель сільськогосподарського призначення. Наголошено на необхідності приведення нормативної грошової оцінки земель сільськогосподарського призначення до середньоєвропейського рівня та створення Державного банку землі.

Ключові слова: ринок землі, права власності, земельна реформа, оренда, грошова оцінка.

Уже двадцять сім років як Україна є незалежною державою, самостійно проводить реформи, вибирає стратегічні шляхи свого розвитку. Підводячи підсумки цієї діяльності, логічно поставити питання, що за четверть століття ми здобули? Де ми зараз знаходимось серед когорти Європейських країн? Які, де і в чому наші успіхи? Відповідь невтішна, навіть найбільші оптимісти в 90-х не могли собі такого уявити - повний колапс економіки, практично всі реформи ініційовані керівництвом держави починаючи з 1991 року з найкращою метою підвищити рівень життя громадян призвели до його повного зубожіння. Сьогодні практично всі стратегічні галузі держави «стоять на колінах», зруйновані, знищені, «прихватизовані» спритними чиновниками, олігархами, політиками і наближеними до них особами. Для того, щоб поставити жирну крапку в стратегії знищення держави, лишилось тільки таким же чином завершити земельну реформу. Маскуючись під захисників селян (власників паїв), меценатів, які сплять і бачать як би зробити їх заможними - ініціюють законодавчі акти, що дозволять відібрати у сьогоднішніх землевласників за безцінь їхні наділи.

Відповідь на запитання: «чи дійсно аграрній державі потрібен ринок землі?» Є риторичною - це все мало бути здійснене ще в 90-х роках минулого століття разом із роздержавленням та передачею земель у колективну та приватну власність. Адже запровадження ві- 
льного обігу земель сільськогосподарського призначення в Україні $€$ пріоритетним як для сільськогосподарських товаровиробників, так і економістів-аграріїв, політиків та інших фахівців, прямо чи опосередковано пов'язаних з аграрною сферою. Пояснюється це тим, що земля $€$ не лише головним засобом виробництва в сільському господарстві, а й важливою складовою виробничого капіталу, одним із найважливіших економічних ресурсів, який посідає центральне місце у світовій політиці та стратегії економічного розвитку будь-якої держави. Слід зазначити, що, володіючи таким потужним природноресурсним потенціалом, аграрний сектор України сьогодні значно відстає від провідних країн світу за продуктивністю праці, урожайністю сільськогосподарських культур, продуктивністю тварин та іншими показниками.

Теоретичні й практичні основи формування ринку землі розглядали такі відомі класики економічної науки, як В. Петті, Ф. Кене, А.Р.Ж. Тюрго, А. Сміт, Д. Рікардо, Дж. Ст. Мілль, К. Маркс та ін. Також величезний внесок у вирішення цієї проблеми зробили вітчизняні вчені-економісти В. Андрійчук, П. Гайдуцький, Ю. Лупенко, М. Малік, Б. Пасхавер, П. Саблук, М. Федоров, В. Юрчишин, А. Мартин та багато інших.

Метою статті $€$ дослідження законопроектів щодо побудови моделі формування ринку сільськогосподарських земель в Україні, виявлення їх сильних та слабких сторін.

Дослідженнями встановлено, що питання формування економічного механізму земельних відносин у частині володіння, користування й розпорядження земельними ресурсами є пріоритетом аграрної політики в Україні, починаючи з 1990 року. Зокрема, Постанова Верховної Ради України «Про прискорення земельної реформи та приватизацію землі» від 13 березня 1992 р. стала поштовхом до роздержавлення земель та безоплатної передачі їх у колективну та приватну власність, завдяки чому Україна отримала значне зростання частки приватного сектора в сільському господарстві, станом на 01.01.2017 р. 31,1 млн га площ сільськогосподарських угідь перебувають у приватній власності [1]. Але це тільки перший крок у земельній реформі.

Відсутність вільного ринку землі, уведення якого уже впродовж десятків років в Україні відтерміновується, призвело до неефективного використання земельних ресурсів, структурної розбалансованості аграрного сектора, депресивності сільських територій, до безробіття та зубожіння сільського населення. Основними виробниками сільськогосподарської продукції стали не дрібні фермерські госпо- 
дарства, а агрохолдинги, які практично за безцінь орендують сільськогосподарські землі у їх власників не створюючи при цьому будьяких агропереробних потужностей. Вся їхня діяльність зводиться до вирощування технічних та зернових культур з метою їх подальшого експорту та отримання максимального прибутку. При цьому якість сільськогосподарських угідь без дотримання сівозмін, внесення органіки, запобігання деградаційним процесам і т.д. дуже швидкими темпами погіршується.

3 метою виявлення майбутньої моделі формування ринку сільськогосподарських земель в Україні нами був проаналізований законопроект «Про обіг земель», що підготували депутати аграрного комітету парламенту за ініціативи в. о. голови аграрного комітету Олександра Бакуменка. У грудні 2018 року проект був розглянутий на засіданні робочої групи аграрного комітету. Також його обговорення відбулося 16 січня, а упродовж 2019 року його планують обговорити в широкому колі на рівні місцевих громад. Ключові елементи даного законопроекту представлені нижче [2]:

1. Іноземці та іноземні компанії не зможуть скористатися правом володіння українською землею. До повноцінного запуску ринку землі діятиме перехідний період. Автори пропонують, щоб з 2019 по 2024 роки право купувати землю отримали лише фізичні особи громадяни України.

2. До 2021 року пропонується дозволити купувати державну і комунальну землю громадянам України та фермерським господарствам для створення або розширення сімейного фермерського господарства: без статусу юридичної особи - до 20 га, із статусом юридичної особи - до 200 га.

Громадянин України може бути засновником або членом лише одного фермерського господарства.

3. Після 2024 року право купувати землю пропонується надати українським аграрним компаніям (агрохолдингам), які останні три роки $є$ сільськогосподарськими виробниками, тобто доходи яких від реалізації вирощеної ними аграрної продукції за останні три роки становили понад 75\%.

4. У документі передбачені обмеження на придбання земель фізичними та юридичними особами. Так, фізична особа, яка не займалася сільським господарством, зможе придбати до 200 га землі. Якщо фізична особа була фермером п'ять років, їй дозволять купити до 500 га, якщо десять років - 2 тис. га. Ці розміри ділянок можуть бути збільшені у разі їх успадкування за законом.

5. Українські компанії зможуть сконцентрувати 30\% аграрних земель району, 15\% земель області, 0,5\% земель України. За рішен- 
ням обласної ради, загальний розмір ділянок компаній на території області може бути зменшений.

6. У проекті закону визначено, що контролювати концентрацію земель буде орган, який веде державний земельний кадастр. Крім того, він буде здійснювати моніторинг стану земельних відносин. Зараз таким органом є Держгеокадастр.

7. Автори проекту вважають, що ціна на землю мусить дорівнювати експертній грошовій оцінці, встановленій на час продажу ділянки, крім тих, що виставлені на земельні торги. Ціна не може бути нижчою за нормативно-грошову оцінку.

8. Першими купувати землю матимуть право члени сім'ї власника ділянки, її орендарі, власники та користувачі суміжних ділянок, місцеві фермерські господарства.

9. Власники матимуть право продавати землю через електронні аукціони. Державну та комунальну землю пропонується реалізовувати лише через електронні аукціони.

10. Проект закону також передбачає умови обміну сільськогосподарськими земельними ділянками та умови зміни цільового призначення таких ділянок.

Закон «Про ринок сільськогосподарських земель» має враховувати інтереси всіх стейкхолдерів. Яким же чином даний законопроект полегшить життя селян, власників паїв, за що так палко борються законодавці? Аналіз показує - що ніяк. Законопроект захищає права великого українського олігархату, агрохолдингів і т.д., але аж ніяк не права селян. Обмеження фермерських господарств 20 або 200 га сільськогосподарських угідь не дасть їм можливості побудувати замкнутий цикл виробництва, а отже і надію на успіх, створення додаткових робочих місць (тваринні комплекси, м'ясо- та молокопереробні комбінати і т.д.).

Складається враження, що землю у селян збираються забрати за безцінь, щоб потім збагатитися в десятки або й сотні разів. Що означає - земля не може бути нижчою за нормативно-грошову оцінку? А хто визначає цю нормативно-грошову оцінку в Україні і чи вона дійсно відповідає ринку (європейському чи світовому)? Проведені нами дослідження показали, що нормативно-грошова оцінка 1 га української ріллі та перелогів коливається в середньому в межах від 800 дол. до 1 тис. євро залежно від регіону (рисунок). Ціна ж природніх пасовищ та сіножатей, взагалі сміхотворна - від 3 тис. грн до 14 тис. грн за 1 га.

У цілому площа сільськогосподарських земель в Україні становить 42,7 млн гектарів, або 70 відсотків площі усієї території країни, а 
площа ріллі - 32,5 млн гектарів, або 78,4 відсотка усіх сільськогосподарських угідь [4].

Сільськогосподарські угіддя становлять близько $19 \%$ загальноєвропейських, у тому числі рілля - близько $27 \%$. Показник площі сільськогосподарських угідь у розрахунку на одну особу $\epsilon$ найвищим серед європейських країн і становить 0,9 гектара, у тому числі 0,7 гектара ріллі (середній показник європейських країн - 0,44 і 0,25 гектара відповідно). Площа чорноземів в Україні становить від 15,6 млн до 17,4 млн гектарів, або близько 8 відсотків світових запасів [4].

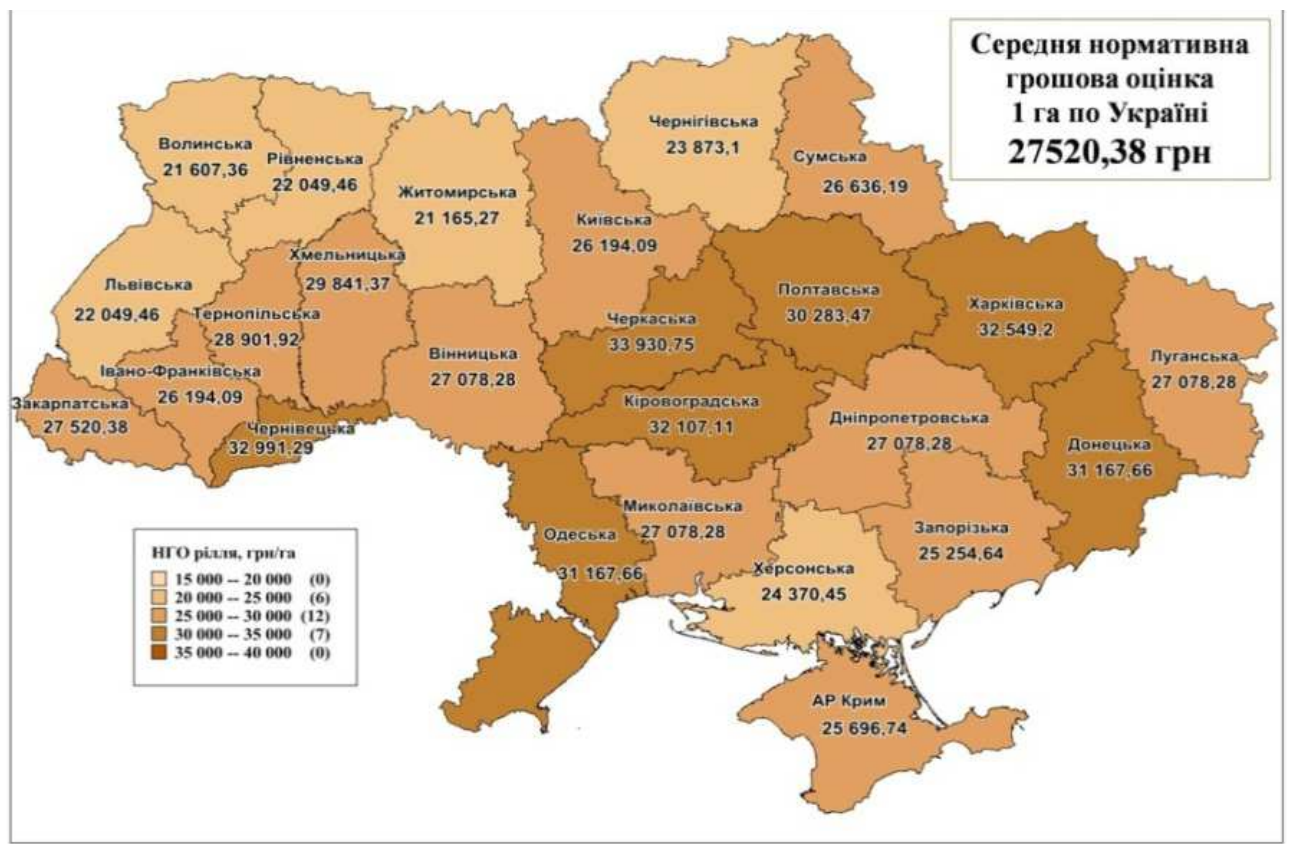

Рисунок. Середня нормативна грошова оцінка 1 га ріллі та перелогів по Україні на 01.01.2018 (за даними офіційного веб-сайту Держгеокадастру)

3 огляду на обмежені матеріальні ресурси власників земельних часток (паїв), практично єдиним способом їх існування на селі залишається передача земельних ділянок в оренду. Цією ситуацією користуються агрохолдинги, визначаючи умови та занижену вартість орендної плати (середній розмір орендної плати на рік становить 1093 гривні за 1 гектар).

Орендна ж плата за землі сільськогосподарського призначення у світі є високою, зокрема у Німеччині, Нідерландах та Данії вона становить більше 200 євро за 1 гектар ріллі, у США - до 10 відсотків ринкової вартості, або 350-400 доларів США за 1 гектар; у Канаді на оплату оренди витрачається 40-45 відсотків вирощеного врожаю, у 
Франції - до однієї третьої врожаю.

На наш погляд, ціна на сільськогосподарські землі в Україні має бути ринковою і відповідати середньоєвропейській, а чорноземи і того вище. Збільшення вартості сільськогосподарських угідь призведе відповідно до збільшення їх оренди, а отже і встановлення соціальної справедливості.

Дослідження проведені нами, щодо становлення ринку землі в європейських країнах показали, що всі вони є різними і мають свої національні та державні особливості. Вартість ріллі у межах регіонів окремих країн Європейського союзу представлено в таблиці [3].

Таблиця

Варіативна вартість ріллі у межах регіонів окремих країн

Європейського союзу, євро/га

\begin{tabular}{|l|c|c|}
\hline \multicolumn{1}{|c|}{ Країна } & $\min$ & $\max$ \\
\hline Болгарія & 2 & 3 \\
\hline Чехія & 1166 & 6008 \\
\hline Данія & 4384 & 5630 \\
\hline Естонія & 18412 & 30871 \\
\hline Ірландія & 2735 & 2735 \\
\hline Греція & 17998 & 22844 \\
\hline Іспанія & 5744 & 55515 \\
\hline Франція & 6237 & 94213 \\
\hline Хорватія & 2600 & 12680 \\
\hline Італія & 2739 & 4651 \\
\hline Латвія & 16498 & 108611 \\
\hline Литва & 2917 & 2917 \\
\hline Люксембург & 3516 & 3516 \\
\hline Угорщина & 26030 & 26030 \\
\hline Нідерланди & 2786 & 4856 \\
\hline Польща & 49250 & 77834 \\
\hline Румунія & 5324 & 12396 \\
\hline Словенія & 1863 & 2059 \\
\hline Словаччина & 14220 & 32982 \\
\hline Фінляндія & 14700 & 49550 \\
\hline Швеція & 4980 & 11065 \\
\hline Великобританія & 1637 & 15958 \\
\hline
\end{tabular}

Не допуск на ринок сільськогосподарських земель іноземних інвесторів, це не захист селян, це захист олігархами своїх мерканти- 
льних інтересів, оскільки селянину при продажі своєї землі неважливо хто заплатить за неї ринкову вартість, іноземний інвестор чи український олігарх, адже це ринок.

Висновки. Отже, ініціатива аграрного комітету Верховної ради України $є$ позитивною для громадян тільки з тієї позиції, що вона $\epsilon$ першою серед трьох гілок влади, які мали це зробити. Наступні кроки за Кабінетом міністрів України та за Президентом, які мають врахувати всі недоліки законопроекту нинішнього і запропонувати суспільству альтернативу, яка врахує побажання всіх стейкхолдерів, а не тільки інтереси великого бізнесу.

На наш погляд, найбільш цінним ресурсом країни (землями) мала б розпоряджатись держава, враховуючи свої національні особливості. Кожен селянин, або власник паю має мати право продати за бажанням свою «нерухомість», але тільки Державному банку землі, за ринковими європейськими цінами. А уже банк, через земельні аукціони надавати у довгострокову оренду землі будь-якому інвестору (вітчизняному, закордонному), хто більше заплатить з обов'язковою вимогою дотримання збереження якісних характеристик земель, розбудовою переробних виробничих потужностей в регіоні оренди сільськогосподарських угідь (об'єднаних територіальних громад). За недотримання цих вимог передбачити великі штрафні санкції.

Розпочати варто із створення Державного банку землі. Початкове накопичення капіталу має відбуватись через земельні аукціони шляхом довгострокової оренди земель державної та комунальної власності.

Так, процедура потребує значних зусиль, розробку великої кількості підзаконних актів, а головне - ліквідацію корупції, що дуже непросто. Але в умовах війни, зубожіння населення, тільки успішна земельна реформа в Україні може стати тим самим локомотивом, який зможе перезапустити економіку країни, зберегти незалежність та дати суспільству ще один шанс на щасливе майбутнє у рідній країні.

1. Огляд стану земельних відносин в Україні [Електронний ресурc]. URL: file:///C:/ Users/\%D0\%A2\%D0\%B0\%D0\%BD\%D1\%8E\%D1\%88\% D0\%BA\%D0\%B8\%D0\%BD\%D0\%B0/ Downloads/ Land-ReviewMonthly_3_final-1.pdf. (дата звернення: 15.03.2019). 2. Пирожок О. Економічна правда. Як будуть продавати і купувати землю: новий законопроект. 2019. URL: https://www.epravda.com.ua/publications/2019/01 /22/64450. (дата звернення: 15.03.2019). 3. Вартість сільськогосподарських земель та ї оренди у країнах Європейського союзу та Україні. URL: http:// zemvisnuk.com.ua/ page/vart-st-zemel-ta-kh-orendi. (дата звернення: 15.03.2019). 4. Деякі питання удосконалення управління в сфері викорис- 
тання та охорони земель сільськогосподарського призначення державної власності та розпорядження ними : Постанова Кабінету міністрів України від 7 червня 2017 р. № 413. URL: https://www.kmu.gov.ua/ua/npas/ 250068882. (дата звернення: 15.03.2019).

\section{REFERENCES:}

1. Ohliad stanu zemelnykh vidnosyn v Ukraini [Elektronnyi resurs]. URL: file:///C:/ Users/\%D0\%A2\%D0\%B0\%D0\%BD\%D1\%8E\%D1\%88\% D0\%BA\%D0\%B8\%D0\%BD\%D0\%B0/ Downloads/ Land-ReviewMonthly_3_final-1.pdf. (data zvernennia: 15.03.2019). 2. Pyrozhok 0. Ekonomichna pravda. Yak budut prodavaty $i$ kupuvaty zemliu: novyi zakonoproekt. 2019. URL: https://www.epravda.com.ua/publications/2019/01 /22/64450. (data zvernennia: 15.03.2019). 3. Vartist silskohospodarskykh zemel ta yikh orendy u krainakh Yevropeiskoho soiuzu ta Ukraini. URL: http:// zemvisnuk.com.ua/ page/vart-st-zemel-ta-kh-orendi. (data zvernennia: 15.03.2019). 4. Deiaki pytannia udoskonalennia upravlinnia v sferi vykorystannia ta okhorony zemel silskohospodarskoho pryznachennia derzhavnoi vlasnosti ta rozporiadzhennia nymy : Postanova Kabinetu ministriv Ukrainy vid 7 chervnia 2017 r. № 413. URL: https://www.kmu.gov.ua/ua/npas/ 250068882. (data zvernennia: 15.03.2019).

Shvets F. D., Candidate of Engineering (Ph.D.), Associate Professor, Pakharenko O. V., Candidate of Economics (Ph.D.), Associate Professor (National University of Water and Environmental Engineering, Rivne)

\section{DEVELOPMENT OF THE LAND MARKET IN UKRAINE: WISH OR NECESSITY}

The results of research on the problems of the land market in Ukraine are represented. The analysis of bills on the land market in Ukraine has been conducted and their positive and negative aspects have been identified. A number of practical recommendations for the development of the agricultural land market are proposed. However, we consider, that every villager or shareholder should have the right to sell his 'real estate', but only to the State Land Bank (which must be created), at market prices at European level. The bank provides through land auctions long-term lease of land to any investor (domestic, foreign) who will pay more with the obligatory requirement to maintain the quality characteristics of land and the development of processing capacity in the region of lease of agricultural land (united 
territorial communities). For the development of a Ukrainian village, the restriction of potential tenants in the area of $\mathbf{2 0}$ or $\mathbf{2 0 0}$ hectares of agricultural land is impossible. the The success of the farmer (the tenant, the investor) is possible only by means of free circulating capital which can be obtained through a closed cycle of production (agricultural products, livestock complexes, processing enterprises , sales, cash). For this purpose it is necessary to have agricultural lands with the area from $\mathbf{2 0 0 0}$ hectares. The article also emphasizes the urgent need to bring normative monetary valuation of agricultural land to the average European level.

Keywords: land market, property rights, land reform, lease, monetary valuation.

Швец Ф. Д., к.Т.н., доцент, Пахаренко О. В., к.э.н., доцент (Национальный университет водного хозяйства и природопользования, г. Ровно)

ФОРМИРОВАНИЕ РЫНКА ЗЕМЛИ В УКРАИНЕ: ПРИХОТЬ ИЛИ НЕОБХОДИМОСТЬ

Приведены результаты исследования проблем становления рынка земли в Украине. Проведен анализ законопроектов о рынке земель в Украине, выявлены их положительные и отрицательные стороны. Предложен ряд практических рекомендаций по развитию рынка земель сельскохозяйственного назначения. Отмечена необходимость приведения нормативной денежной оценки земель сельскохозяйственного назначения до среднеевропейского уровня и создание Государственного банка земли.

Ключевые слова: рынок земли, права собственности, земельная реформа, аренда, денежная оценка. 